\title{
ANALISIS EMPIRIS: SOLUSI PERKULIAHAN DI ERA NORMAL BARU
}

\author{
M. Ardiansyah ${ }^{1 *}$, Mohamad Lutfi Nugraha ${ }^{2}$ \\ Universitas Indraprasta PGRI, Indonesia ${ }^{12}$ \\ m.ardiansyah_unindra@yahoo.co.id ${ }^{1}$
}

\begin{abstract}
Received: 19 November 2020 Wabah pandemi corona virus disease 19 menyebabkan universitas tutup Revised: 28 November 2020 sementara untuk dapat menghindari penularan penyebarannya virus Accepted: 18 Februari 2021 corona. Hal tersebut membuat berbagai aktivitas harus dirubah menjadi pembelajaran daring termasuk di perguruan tinggi. Penelitian ini membahas tentang semua aktivitas menuju normal baru dalam menyelenggarakan perkuliahan daring terkait penggunaan enam strategi yang diterapkan oleh dosen di Universitas Indraprasta PGRI Jakarta. Dalam kurun waktu normal baru, penelitian ini mengungkap enam strategi penyelenggaraan perkuliahan daring yaitu; a) strategi kontekstualisasi, b) strategi penyampaian yang tepat, c) strategi adaptasi yang tinggi dalam menggunakan teknologi, d) strategi dukungan yang memadai, e) strategi partisipasi yang berkualitas, f) strategi proses yang berkelanjutan. Adapun hasil yang diperoleh (1) Dosen memiliki rencana pembelajaran yang berani. (2) Menyediakan alat audio terbaik di perangkat pengajaran daring. (3) Mengorganisir kelas kecil dengan membagi giliran kelas sebanyak 1215 mahasiswa dalam satu sesi jadwal pengajaran. (4) Memerintahkan mahasiswa untuk menggali berbagai sumber belajar dari luar kelas (5) Menggabungkan antara pengajaran daring dan pembelajaran tatap muka dengan menginstruksikan mahasiswa untuk menghadiri kelas jarak jauh. (6) Menuntut mahasiswa menyelesaikan tugas yang diberikan.
\end{abstract}

Keywords: Covid-19; New Normal; Perkuliahan Daring

(*) Corresponding Author: $\quad$ Ardiansyah, m.ardiansyah_unindra@yahoo.co.id, +62 87888392696.

How to Cite: Ardiansyah, M., Nugraha. L. M. (2020). Analisis Empiris: Solusi Perkuliahan Di Era Normal Baru. Research and Development Journal of Education, 7 (1), 182-192.

\section{INTRODUCTION}

Wabah Covid-19 bermula di Wuhan, Cina (Culp, 2020) dan telah diumumkan sebagai pandemi oleh organisasi kesehatan dunia (Sohrabi et al., 2020). Mengantisipasi penularan virus tersebut pemerintah telah mengeluarkan berbagai kebijakan, seperti isolasi, social and physical distancing hingga pembatasan sosial berskala besar (Siregar \& Zahra, 2020). Kondisi ini mewajibkan semua masyarakat untuk tetap stay at home, bekerja, beribadah dan belajar di rumah. Virus corona turut serta mempengaruhi dunia pendidikan dimana proses belajar mengajar yang biasanya dilakukan secara tatap muka diruang kelas dan sekarang harus dilakukan melalui pembelajaran jarak jauh, atau belajar dari rumah (Pakpahan \& Fitriani, 2020). Terkecuali lembaga pendidikan yang harus mengikuti aturan pemerintah untuk melakukan inovasi dalam proses pembelajaran ketika terjadi bencana alam atau pandemi global melalui pembelajaran daring untuk meningkatkan mutu pembelajaran (Sarip et al., 2020).

Sejak pertengahan Maret 2020, saat terjadi pandemi covid-19, seluruh perguruan tinggi di Indonesia menghapus dan mengadaptasi era normal baru dalam mengaplikasikan berbagai metode pembelajaran, dari interaksi tatap muka di kelas menjadi pendidikan via 
daring (Windhiyana, 2020). Integrasi penggunaan teknologi menawarkan peluang yang begitu banyak jumlahnya, sehingga dapat mengarah pada pengalaman belajar yang lebih baik, tidak terkecuali pembelajaran daring (Fitriyadi, 2013). Kebijakan terhadap wabah pandemi ini sengaja dibuat oleh pemerintah Indonesia dengan meminta semua institusi pendidikan agar melakukan pembelajaran di rumah dengan memaksimalkan penggunaan teknologi sistem daring.

Perkuliahan daring merupakan sarana utama dalam pembelajaran ketika wabah Pandemi Covid-19 (Widiyono, 2020). Semua peserta didik dalam melaksanakan pembelajaran daing menggunakan smartphone, notebook agar mereka tetap tinggal di rumah dan mendapatkan pelajaran serta ilmu dari para dosen. Sampai saat ini perkembangan ilmu pengetahuan telah menghantarkan masyarakat menuju babak baru yaitu babak yang memanfaatkan peralatan-peralatan yang merupakan hasil dari teknologi (Ratnaya, 2011). Selain Indonesia, ada beberapa negara lain di seluruh dunia yang terjebak dalam wabah Covid-19.

Proses belajar mengajar di perguruan tinggi pada masa penyebaran pandemi covid19 menyebabkan institusi pendidikan tidak dapat melakukan interaksi tatap muka di dalam kelas. Hal tersebut membuat perguruan tinggi berpikir keras untuk mengatasi kesulitan belajar yang dihadapi para dosen dan mahasiswanya. Pendidikan daring dipilih untuk menempati hubungan akademis antara dosen dan mahasiswa. Shishkovskaya et al (2015) berdebat tentang pengajaran pembelajaran bahasa asing "tanpa kertas". Pengajaran daring menggunakan kontribusi tanpa kertas dalam mendistribusikan materi serta menyerahkan tugas. Selain itu, (Oproiu (2015) melakukan penelitian tentang penggunaan e-learning platform (Moodle) dalam proses pengajaran di universitas.

Lebih banyak penelitian tentang pengajaran daring telah dijelaskan oleh para penulis berikut ini; (Brinkley-Etzkorn, 2018): Belajar mengajar daring; Mengukur pengaruh pelatihan pengembangan fakultas pada efektivitas pengajaran melalui lensa TPACK, Pothkow \& Hege (2011): Ruang kelas teologi daring: Strategi untuk melibatkan komunitas pembelajar jarak jauh dalam model hybrid pendidikan daring, Jenkins (2014): Kepemimpinan pengajaran daring: Sebuah studi eksplorasi penggunaan strategi instruksional dan penilaian. (Cowan, 2014): Perspektif Konektivisme dari Transisi dari tatap muka ke pengajaran daring di pendidikan tinggi.

\section{LITERATURE REVIEW}

Penggunaan teknologi dalam new normal teaching membuat para dosen dan mahasiswa harus menyadari untuk menggunakan pembelajaran daring selaras dengan masa pandemi. Asamoah \& Oheneba-Sakyi (2017) menyebutkan tentang prinsip konstruktivis yang diterapkan dalam proses belajar mengajar yang dimediasi TIK: perspektif pendidikan tinggi. Pembahasan tentang internet, Communication and Technology (ICT) juga telah dielaborasi oleh beberapa penulis seperti; Honkapuro et al (2015) menyebutkan bahwa dampak dari pengalaman belajar otentik dengan TIK pada niat dosen pra-jabatan untuk menggunakan TIK untuk pengajaran dan pembelajaran. $\mathrm{Wu}$ et al (2018) menerima penerimaan sistem pengajaran dan pembelajaran yang dimediasi TIK untuk dosen: Efek moderasi gaya kognitif. Kweka \& Ndibalema (2018) menyampaikan kendala yang menghambat adopsi TIK di Tanzania: Kasus Distrik Hanang.

Berdasarkan kajian penelitian di atas, sebagai perguruan tinggi di Indonesia hanya melahirkan ratusan penyelenggara pendidikan daring. Di Indonesia harus segera meningkatkan kemampuan dan keterampilan sumberdaya manusia Indonesia melalui pendidikan dengan melahirkan operator dan analis handal bidang pendidikan sebagai 
pendorong kemajuan pendidikan berbasis teknologi informasi di Indonesia menjawab tantangan Industri 4.0 yang terus melaju pesat (Syamsuar \& Reflianto, 2019). Sejalan dengan kemajuan teknologi informasi dan komunikasi, kini pendekatan pembelajaran telah berubah ke arah pembelajaran abad pengetahuan. Orang dapat belajar di mana saja, kapan saja, dengan siapa saja. Itulah ciri pembelajaran abad pengetahuan yang dikenal sebagai berbasis komputer (Kuntarto, 2017). Pembelajaran berbasis komputer adalah pengelolaan pembelajaran dengan memanfaatkan perangkat (baik perangkat keras maupun perangkat lunak) komputer. Pemanfaatan perangkat komputer juga sering diidentikkan dengan penggunaan jaringan situs internet, namun sebetulnya komputer tidak terbatas pada perangkat komputer dan internet melainkan juga meliputi media informasi seperti televisi, radio, multimedia player, handphone dan beragam piranti komputer lainnya (Rosdiana, 2018).

Wabah pandemi tersebut meminta institusi perguruan tinggi membuat berbagai macam program pendidikan daring untuk menampung 15.000 mahasiswa sarjana agar tetap di rumah serta memiliki pengajaran virtual dan mendapatkan transfer ilmu dari dosen selama masa normal baru. Terutama, Penelitian ini memfokuskan solusi pembelajaran daring dengan memunculkan resolusi empiris dengan mempromosikan enam strategi pengajaran pendidikan daring di Universitas Indraprasta PGRI yaitu (1) Dosen memiliki rencana pembelajaran yang berani. (2) Menyediakan alat audio terbaik di perangkat pengajaran daring. (3) Mengorganisir kelas kecil dengan membagi giliran kelas sebanyak 12-15 mahasiswa dalam satu sesi jadwal pengajaran. (4) Memerintahkan mahasiswa untuk menggali berbagai sumber belajar dari luar kelas (5) Menggabungkan antara pengajaran daring dan pembelajaran tatap muka dengan menginstruksikan mahasiswa untuk menghadiri kelas jarak jauh. (6) Menuntut mahasiswa menyelesaikan tugas yang diberikan. Oleh karena itu, peneliti mengajukan satu masalah penelitian yaitu "Bagaimana Universitas Indraprasta PGRI menyesuaikan strategi pengajaran pendidikan daring untuk menghadapi pandemi Covid-19?"

Wabah Covid-19 membawa orang di seluruh dunia untuk mengubah metode mereka dari cara tradisional ke cara yang lebih berteknologi dalam pengajaran. Tampak jelas bahwa dalam pembelajaran kovensional, seperti yang dilakukan dosen sehari-hari dimana mereka dapat mengakomodasi interaksi tatap muka langsung kepada mahasiswa. Selain itu, dosen dapat memaksimalkan kekuatan bahasa tubuh, ekspresi wajah, dan suara dosen agar mahasiswa memahami materi yang dijelaskan. Di era wabah Covid-19 seperti saat ini, dosen sepertinya tidak bisa menggunakan ketiga elemen tersebut secara jelas dan langsung karena seluruh elemen yang ada di universitas harus beralih ke platform daring seperti zoom meeting dan google classroom.

Para pendidik Indonesia telah terbiasa menerapkan e-learning melalui platform online yang dapat di akses melalui internet. Pesatnya perkembangan teknologi informasi terutama internet membuka peluang bagi pengembangan layanan informasi yang lebih baik di lembaga pendidikan (Lestari, 2020). Menurut penelitian Suto (2013) menunjukkan bahwa sebagian besar sarjana Indonesia telah melek TIK untuk mendukung kesiapan mereka dalam menghadapi pendidikan daring.

Review tentang penggunaan e-learning telah dieksplorasi oleh penulis berikut ini seperti; Horspool \& Lange (2012) mengatakan penerapan beasiswa belajar mengajar: persepsi mahasiswa, perilaku dan kesuksesan daring dan tatap muka. Lameras et al (2012) menjelaskan pengajaran universitas campuran menggunakan lingkungan pembelajaran virtual: konsepsi dan pendekatan. Donlan (2014) menyebutkan Exploring the views of students on use of Facebook in university teaching and learning. Macdicken et al (2015) menyatakan tentang akankah MOOCs mengubah pembelajaran dan pengajaran di perguruan tinggi? Keterlibatan dan retensi kursus dalam penyediaan pembelajaran daring. Massive open online courses (MOOCs) require individual learners 
to be able to self-regulate their learning, determining when and how they engage. However, MOOCs attract a diverse range of learners, each with different motivations and prior experience. This study investigates the self-regulated learning (SRL) learners apply in a MOOC, in particular focusing on how learners' motivations for taking a MOOC influence their behaviour and employment of SRL strategies (Littlejohn et al., 2016). Hege (2011) menguraikan kelas teologi daring: strategi untuk melibatkan komunitas pelajar jarak jauh dalam model hibrida pendidikan daring. Do \& Chen (2013) mengeksplorasi faktor-faktor yang mempengaruhi niat teknologi pendidikan masa depan untuk berpartisipasi dalam pengajaran daring. Sangrà et al (2015) mengambil studi tentang tingkat kemahiran dan kebutuhan pengembangan profesional dalam peran pengajaran daring perifer.

Pembelajaran daring yang diterapkan di Universitas Indraprasta PGRI berjalan dengan cukup baik. Banyak dosen yang mengajar menggunakan Platform whatsapp yang hanya mengirim materi dan memberikan tugas. Ini tentunya akan menambah kesulitan yang dialami oleh mahasiswa. Oleh karena itu dosen senantiasa agar dapat memberikan pelajaran yang lebih kepada mahasiswa agar tujuan pembelajaran berlangsung dengan maksimal. Selain itu, penting untuk menyoroti pendekatan normal baru agar pengambil keputusan dan dosen mampu menganalisis peluang dan tantangan yang mungkin dihadapi dosen dan mahasiswa dalam proses belajar mengajar pada periode pasca covid-19. Oleh karena itu, desain kurikulum normal baru sangat mendesak untuk membimbing dosen dalam memecahkan masalah sekaligus mendapatkan solusi dalam pengajaran dengan mempertimbangkan tujuan, isi, pendekatan, dan materi evaluasi (Cahapay, 2020). Lebih lanjut, Covid-19 dalam setting new normal tidak hanya mempengaruhi isi pengajaran dan kurikulum, kebiasaan tindakan pasca wabah Covid-19 membawa manusia pada aktivitas baru yang harus diterapkan dimanapun mereka berada, yaitu memakai masker, cuci tangan, menjaga jarak fisik.

Penerapan platform pengajaran dan pembelajaran daring, serta menjaga kesehatan tubuh dengan lebih banyak mengkonsumsi Vitamin C dan makanan sehat (Ippolito et al., 2020). Selain itu, di era normal baru ini, dosen juga harus memperhatikan tidak hanya untuk menyarankan mahasiswa agar memiliki tubuh yang sehat, tetapi juga cenderung menjauhkan mahasiswa dari efek psikologis dari pembelajaran daring seperti stres dan takut kehilangan nilai akademik. Oleh karena itu, memiliki rencana belajar mengajar yang memadai serta pengembangan profesionalitas dosen disarankan untuk ditingkatkan guna menyesuaikan kondisi pandemi ini (Kahfi, 2020).

Melalui bantuan platform zoom meeting dan Google classroom sebagai media pembelajaran, maka akan dapat memudahkan para pendidik dan peserta didik dalam proses belajar mengajar. Dengan catatan peserta didik dapat terpantau perkembangannya oleh pendidik maupun orang tua. Google Classroom merupakan aplikasi yang memungkinkan terbentuknya kelas di dunia maya (Utami, 2019). Selain itu, Google Classroom diharapkan mampu memberi kemudahan pada dunia pendidikan karena dapat diakses kapan saja, dimana saja, dan dapat menghubungkan dosen dan mahasiswa saat di luar atau pun di dalam kelas (Sari, 2019). Penggunaan aplikasi Zoom Meeting cukup efektif bagi para mahasiswa, ini dikarenakan karena adanya komunikasi dua arah antara dosen dan mahasiswa.

\section{METHODS}

Ini adalah desain penelitian kualitatif deskriptif. Penulis mengambil mahasiswa perguruan tinggi di Universitas Indraprasta PGRI sebagai sampel penelitian secara acak. Mengeksplorasi observasi sebagai instrumen pengumpulan data melalui google form yang 
link nya dibagikan ke mahasiswa. Ada beberapa tahapan dalam menganalisis data, (Miles et al., 2014) yaitu; reduksi data, penyajian data, penarikan simpulan data. Pertama, penulis melakukan reduksi atas semua data yang didapat dari tanggapan mahasiswa di google form yang mereka komentari tentang pendidikan daring yang diadakan di Universitas Indraprasta PGRI. Kedua, penyajian data dilakukan melalui tabulasi data, pengklasifikasian data, pengkategorian data dan analisis data. Terakhir, ketiga, penulis menyimpulkan temuan dan membahas hasil analisis berkenaan dengan jawaban masalah penelitian.

\section{RESULTS \& DISCUSSION}

\section{Results}

Institusi harus bekerja keras untuk memberikan apapun dalam menyelenggarakan pendidikan daring seperti; koneksi internet, materi daring, aplikasi audio dan video, dan fasilitas perangkat keras. Terlebih lagi, para dosen perlu mendobrak tantangan saat ini untuk mempersiapkan diri dalam menyelenggarakan pengajaran daring di bawah pengalaman mengajar yang memadai dan minimnya teknologi tinggi. Anehnya, pada saat wabah Covid-19 ini berpotensi menimbulkan ketidaksiapan dan ketidakmampuan mahasiswa di kemudian hari karena belum adanya kesiapan dalam menerapkan pendidikan daring yang membawa teknologi pada program studi di rumah (Gozali, 2020).

Terdapat banyak platform yang dapat digunakan oleh dosen dalam pengajaran online di era normal baru ini, terutama platform zoom meeting dan google classroom. Aplikasi ini digunakan karena banyak respon positif dari mahasiswa terutama adanya interaksi langsung yang dilakukan antara keduanya.

\section{Discussion}

Penelitian difokuskan pada strategi yang membantu dosen dan mahasiswa dalam melaksanakan pembelajaran daring secara efektif dan menjaga sikap belajar mahasiswa. Kami sudah melakukan observasi; studi ini menjelaskan strategi pengajaran daring untuk memberikan mahasiswa materi dan perangkat pembelajaran secara efektif.

Pertama, buat rencana pengajaran alternatif; Pengajaran daring ini akan bergantung pada sistem daring internet yang membutuhkan perangkat keras dan perangkat lunak komputer yang sangat besar dan visibilitasnya, kita perlu melayani platform yang akan kita gunakan yang berwujud dan mudah dioperasikan bagi mahasiswa. Koneksi dan akses internet menjadi pertimbangan mayoritas yang harus diatasi. Institusi perlu menyediakan terminal internet yang terawat baik di kampus yang mendukung proses pengajaran daring platform selama ini bekas. Mereka juga perlu mengumpulkan mahasiswa yang tidak dapat mengakses platform pengajaran daring dengan menyediakan kuota internet yang memadai.

Kedua, kita perlu memperhatikan suara audio kita; Ketika kita mengadakan pengajaran di kelas konvensional, kita dapat meminta bahasa tubuh mahasiswa, ekspresi wajah, dan berbicara dengan lantang untuk memastikan bahwa suara kita didengarkan dengan baik oleh mahasiswa. Sejak kelas daring, ada beberapa hal terbatas untuk dimiliki seperti; sikap dosen dan mahasiswa di layar, kesiapan, dan keberadaan selama interaksi daring, dan penerimaan materi lengkap. Selain itu, kami juga menemukan beberapa kelemahan pengajaran daring seperti; suara dosen, suara mahasiswa, dan alokasi waktu 
yang sangat singkat. Untuk mengatasi masalah ini dosen harus mengatur suara, slide presentasi, dan waktu dalam sesi pengajaran.

Ketiga, kelas kecil itu indah; Memiliki ruang kelas daring memang tidak mudah bagi mahasiswa universitas Islam. Mereka tidak terus-menerus memberi semangat untuk menghadiri dan bergabung dengan kelas virtual. Beberapa dari mereka merasa malas untuk mengikuti karena tidak memiliki cukup akses kuota internet dan beberapa alasan lainnya. Dosen hendaknya mengelola pelajaran menjadi beberapa bagian sesi seperti; Mengajar materi isi, membagi ruang kelas menjadi kelompok-kelompok kecil, memisahkan materi menjadi topik bahasan kecil, dan menggunakan teknik mengajar yang efektif dan sederhana. Kizilcec et al (2017) memandang tentang strategi pembelajaran mandiri memprediksi perilaku pelajar dan pencapaian tujuan dalam kursus daring terbuka kelas kecil.

Keempat, meningkatkan kompetensi mahasiswa melalui kegiatan di luar kelas; saat melakukan kelas daring, dosen tidak dapat memantau dan mengontrol mahasiswa; lakukan di rumah meskipun mereka bergabung dengan pertemuan kelas kami. Mereka dengan bebas menyembunyikan monitor visual di wajah mereka untuk menjadi pribadi pribadi dan dosen tidak dapat melihat wajahnya dengan gerakan apa pun. Dengan fenomena ini, dosen hanya dapat berinteraksi dengan audiovisual dan slide materi selama pembelajaran daring dan kelas virtual. Oleh karena itu, hasil perancangan ruang kelas daring dapat berjalan dengan efektif jika mahasiswa memiliki adaptasi teknologi tinggi yang mereka dapatkan dari luar dan pengalaman di lapangan saat mengalami trial and error menggunakan platform pembelajaran daring apapun. (Jenkins, 2014) menyebutkan kepemimpinan mengajar secara daring: Sebuah studi eksplorasi penggunaan strategi instruksional dan penilaian. Mereka juga menyambut baik materi dan tugas yang mudah dipahami dan mudah disampaikan melalui media pengajaran daring yang mereka kenal.

Kelima, menggunakan asisten pengajar; Dosen di perguruan tinggi dibagi menjadi dosen junior dan senior. Mereka memiliki pengajaran empiris yang berbeda dengan menggunakan teknologi karena bergantung pada keahlian mata pelajaran mereka. Beberapa dosen suka menggunakan TIK (internet, komunikasi, dan teknologi) beberapa lainnya tidak terbiasa menggunakannya. Berdasarkan data institusi disebutkan bahwa 35 persen dosen adalah dosen senior yang berusia 40 tahun ke atas. Kondisi ini membuat mereka kesulitan dalam bermunculan pengajaran daring menggunakan apapun aplikasi platform. Oleh karena itu, mereka perlu memiliki setiap bagian pelatihan untuk membekali mereka dalam menguasai platform pengajaran daring itu secara komprehensif.

Solusinya adalah dosen senior perlu memiliki asisten pengajar sebelum mengajar mahasiswanya dengan keahliannya. Ini dapat dibentuk dengan memasukkan dosen junior dalam tim pengajar bersama mereka. Dalam tim pengajar, dosen junior akan membantu dosen senior dalam mengoperasikan pengajaran daring menggunakan internet dan teknologi yang diadaptasi, serta dosen junior dapat belajar dari senior tentang materi, referensi, dan penilaian pengajaran yang mendalam. Selain itu, di sini asisten pengajar dapat membantu dosen senior dalam menjaga selama pengajaran daring menggunakan platform baik membantu membuka kelas daring, memproses kelas daring, merancang kelas daring diskusi konten, dan mengatur tugas dan tugas daring mahasiswa.

Keenam, menggabungkan ruang kelas daring dan ruang kelas mandiri; Masalah pengajaran biasanya muncul ketika tidak ada partisipasi yang sangat aktif dari mahasiswa dalam diskusi dan dialog akademik antara dosen-mahasiswa dan mahasiswa-mahasiswa. Akal sehat ini terjadi dalam pengajaran offline atau kelas tatap muka, bahkan lebih buruk lagi di kelas daring saat itu. Untuk mengatasi masalah tersebut, dosen harus mengandalkan dua domain ruang kelas, yaitu; kelas daring dan ruang kelas mandiri. Dalam kelas daring dosen harus aktif dalam mengeluarkan SAP dan mentransfer materi dan pengetahuan, serta mahasiswa diminta untuk hadir dan mengikuti semua proses 
belajar mengajar termasuk aktif dalam bertanya dan menjawab tentang materi. Selain itu, (Windhiyana, 2020) menyatakan bahwa pandangan mahasiswa tentang pengajaran daring yang efektif di pendidikan tinggi. Di sisi lain, di kelas mandiri, dosen secara mandiri menggali lebih banyak materi dari berbagai sumber yang menyenangkan dan menarik, mahasiswa diminta untuk menggali lebih banyak pengetahuan dari sumber lain yang mungkin mereka miliki.

Untuk mendukung pendidikan daring, dosen harus mengatur penilaian akademis mengenai penilaian kognitif dan konten. Lembaga harus memiliki rubrik untuk mengukur keterampilan dan pengetahuan mahasiswa sebagai instrumen dalam menilai proses pengajaran. Keadaan proses belajar mengajar dengan menggunakan kelas daring, dosen mendorong mahasiswa untuk lebih aktif dan kreatif dalam menyerap dan menerima pengetahuan dan materi yang disampaikan oleh dosen, termasuk mengadakan diskusi kelompok kecil virtual, konferensi kelompok virtual, dan presentasi virtual untuk memperkuat pembelajaran. penguasaan mata pelajaran.

Kajian ini menyampaikan implikasi pada pengajaran pedagogik khususnya menghadapi pendidikan daring untuk menjaga protokol kesehatan pada masa pandemi Covid-19. Menurut Do \& Chen (2013) terdapat beberapa faktor yang mempengaruhi niat teknolog pendidikan masa depan untuk berpartisipasi dalam pengajaran daring baik untuk dosen maupun mahasiswa. Implikasi-implikasi inilah yang mungkin bisa menjadi masukan bagi dosen dalam melakukan materi pembelajaran di rumah maupun pembelajaran dari rumah, seperti; Dosen harus kreatif dan inovatif dalam merancang rencana pembelajaran daring. Selanjutnya, dosen perlu memiliki asisten untuk mengoperasikan dan mengelola selama pengajaran daring. Dosen menuntut mahasiswanya untuk aktif dan mandiri dalam menghimpun ilmunya melalui berbagai sumber baik dari internet maupun alam. Terakhir, dosen harus melengkapi dengan perangkat keras dan lunak untuk mensukseskan pendidikan daring di tengah pandemi Covid-19.

\section{CONCLUSION}

Penelitian difokuskan pada strategi yang membantu dosen dan mahasiswa dalam melaksanakan pembelajaran daring secara efektif dan menjaga sikap belajar mahasiswa. Kami sudah melakukan observasi; studi ini menjelaskan strategi pengajaran daring untuk memberikan mahasiswa materi dan perangkat pembelajaran secara efektif.

Pertama, buat rencana pengajaran alternatif; Pengajaran daring ini akan bergantung pada sistem daring internet yang membutuhkan perangkat keras dan perangkat lunak komputer yang sangat besar dan visibilitasnya, kita perlu melayani platform yang akan kita gunakan yang berwujud dan mudah dioperasikan bagi mahasiswa. Koneksi dan akses internet menjadi pertimbangan mayoritas yang harus diatasi. Institusi perlu menyediakan terminal internet yang terawat baik di kampus yang mendukung proses pengajaran daring platform selama ini bekas. Mereka juga perlu mengumpulkan mahasiswa yang tidak dapat mengakses platform pengajaran daring dengan menyediakan kuota internet yang memadai.

Kedua, kita perlu memperhatikan suara audio kita; Ketika kita mengadakan pengajaran di kelas konvensional, kita dapat meminta bahasa tubuh mahasiswa, ekspresi wajah, dan berbicara dengan lantang untuk memastikan bahwa suara kita didengarkan dengan baik oleh mahasiswa. Sejak kelas daring, ada beberapa hal terbatas untuk dimiliki seperti; sikap dosen dan mahasiswa di layar, kesiapan, dan keberadaan selama interaksi daring, dan penerimaan materi lengkap. Selain itu, kami juga menemukan beberapa kelemahan pengajaran daring seperti; suara dosen, suara mahasiswa, dan alokasi waktu 
yang sangat singkat. Untuk mengatasi masalah ini dosen harus mengatur suara, slide presentasi, dan waktu dalam sesi pengajaran.

Ketiga, kelas kecil itu indah; Memiliki ruang kelas daring memang tidak mudah bagi mahasiswa universitas Islam. Mereka tidak terus-menerus memberi semangat untuk menghadiri dan bergabung dengan kelas virtual. Beberapa dari mereka merasa malas untuk mengikuti karena tidak memiliki cukup akses kuota internet dan beberapa alasan lainnya. Dosen hendaknya mengelola pelajaran menjadi beberapa bagian sesi seperti; Mengajar materi isi, membagi ruang kelas menjadi kelompok-kelompok kecil, memisahkan materi menjadi topik bahasan kecil, dan menggunakan teknik mengajar yang efektif dan sederhana. Kizilcec et al (2017) memandang tentang strategi pembelajaran mandiri memprediksi perilaku pelajar dan pencapaian tujuan dalam kursus daring terbuka kelas kecil.

Keempat, meningkatkan kompetensi mahasiswa melalui kegiatan di luar kelas; saat melakukan kelas daring, dosen tidak dapat memantau dan mengontrol mahasiswa; lakukan di rumah meskipun mereka bergabung dengan pertemuan kelas kami. Mereka dengan bebas menyembunyikan monitor visual di wajah mereka untuk menjadi pribadi pribadi dan dosen tidak dapat melihat wajahnya dengan gerakan apa pun. Dengan fenomena ini, dosen hanya dapat berinteraksi dengan audiovisual dan slide materi selama pembelajaran daring dan kelas virtual. Oleh karena itu, hasil perancangan ruang kelas daring dapat berjalan dengan efektif jika mahasiswa memiliki adaptasi teknologi tinggi yang mereka dapatkan dari luar dan pengalaman di lapangan saat mengalami trial and error menggunakan platform pembelajaran daring apapun. (Jenkins, 2014) menyebutkan kepemimpinan mengajar secara daring: Sebuah studi eksplorasi penggunaan strategi instruksional dan penilaian. Mereka juga menyambut baik materi dan tugas yang mudah dipahami dan mudah disampaikan melalui media pengajaran daring yang mereka kenal.

Kelima, menggunakan asisten pengajar; Dosen di perguruan tinggi dibagi menjadi dosen junior dan senior. Mereka memiliki pengajaran empiris yang berbeda dengan menggunakan teknologi karena bergantung pada keahlian mata pelajaran mereka. Beberapa dosen suka menggunakan TIK (internet, komunikasi, dan teknologi) beberapa lainnya tidak terbiasa menggunakannya. Berdasarkan data institusi disebutkan bahwa 35 persen dosen adalah dosen senior yang berusia 40 tahun ke atas. Kondisi ini membuat mereka kesulitan dalam bermunculan pengajaran daring menggunakan apapun aplikasi platform. Oleh karena itu, mereka perlu memiliki setiap bagian pelatihan untuk membekali mereka dalam menguasai platform pengajaran daring itu secara komprehensif.

Solusinya adalah dosen senior perlu memiliki asisten pengajar sebelum mengajar mahasiswanya dengan keahliannya. Ini dapat dibentuk dengan memasukkan dosen junior dalam tim pengajar bersama mereka. Dalam tim pengajar, dosen junior akan membantu dosen senior dalam mengoperasikan pengajaran daring menggunakan internet dan teknologi yang diadaptasi, serta dosen junior dapat belajar dari senior tentang materi, referensi, dan penilaian pengajaran yang mendalam. Selain itu, di sini asisten pengajar dapat membantu dosen senior dalam menjaga selama pengajaran daring menggunakan platform baik membantu membuka kelas daring, memproses kelas daring, merancang kelas daring diskusi konten, dan mengatur tugas dan tugas daring mahasiswa.

Keenam, menggabungkan ruang kelas daring dan ruang kelas mandiri; Masalah pengajaran biasanya muncul ketika tidak ada partisipasi yang sangat aktif dari mahasiswa dalam diskusi dan dialog akademik antara dosen-mahasiswa dan mahasiswa-mahasiswa. Akal sehat ini terjadi dalam pengajaran offline atau kelas tatap muka, bahkan lebih buruk lagi di kelas daring saat itu. Untuk mengatasi masalah tersebut, dosen harus mengandalkan dua domain ruang kelas, yaitu; kelas daring dan ruang kelas mandiri. Dalam kelas daring dosen harus aktif dalam mengeluarkan SAP dan mentransfer materi dan pengetahuan, serta mahasiswa diminta untuk hadir dan mengikuti semua proses 
belajar mengajar termasuk aktif dalam bertanya dan menjawab tentang materi. Selain itu, (Windhiyana, 2020) menyatakan bahwa pandangan mahasiswa tentang pengajaran daring yang efektif di pendidikan tinggi. Di sisi lain, di kelas mandiri, dosen secara mandiri menggali lebih banyak materi dari berbagai sumber yang menyenangkan dan menarik, mahasiswa diminta untuk menggali lebih banyak pengetahuan dari sumber lain yang mungkin mereka miliki.

Untuk mendukung pendidikan daring, dosen harus mengatur penilaian akademis mengenai penilaian kognitif dan konten. Lembaga harus memiliki rubrik untuk mengukur keterampilan dan pengetahuan mahasiswa sebagai instrumen dalam menilai proses pengajaran. Keadaan proses belajar mengajar dengan menggunakan kelas daring, dosen mendorong mahasiswa untuk lebih aktif dan kreatif dalam menyerap dan menerima pengetahuan dan materi yang disampaikan oleh dosen, termasuk mengadakan diskusi kelompok kecil virtual, konferensi kelompok virtual, dan presentasi virtual untuk memperkuat pembelajaran. penguasaan mata pelajaran.

Kajian ini menyampaikan implikasi pada pengajaran pedagogik khususnya menghadapi pendidikan daring untuk menjaga protokol kesehatan pada masa pandemi Covid-19. Menurut Do \& Chen (2013) terdapat beberapa faktor yang mempengaruhi niat teknolog pendidikan masa depan untuk berpartisipasi dalam pengajaran daring baik untuk dosen maupun mahasiswa. Implikasi-implikasi inilah yang mungkin bisa menjadi masukan bagi dosen dalam melakukan materi pembelajaran di rumah maupun pembelajaran dari rumah, seperti; Dosen harus kreatif dan inovatif dalam merancang rencana pembelajaran daring. Selanjutnya, dosen perlu memiliki asisten untuk mengoperasikan dan mengelola selama pengajaran daring. Dosen menuntut mahasiswanya untuk aktif dan mandiri dalam menghimpun ilmunya melalui berbagai sumber baik dari internet maupun alam. Terakhir, dosen harus melengkapi dengan perangkat keras dan lunak untuk mensukseskan pendidikan daring di tengah pandemi Covid-19.

\section{REFERENCES}

Asamoah, M. K., \& Oheneba-Sakyi, Y. (2017). Constructivist tenets applied in ICTmediated teaching and learning: higher education perspectives. Africa Education Review, 14(3-4) ,196-211.

Brinkley-Etzkorn, K. E. (2018). Learning to teach online: Measuring the influence of faculty development training on teaching effectiveness through a TPACK lens. Internet and Higher Education, 3(8), 28-35.

Cahapay, M. B. (2020). Social Distancing Practices of Residents in a Philippine Region with Low Risk of COVID-19 Infection. European Journal of Environment and Public Health, 4(2), em0057.

Cowan, N. (2014). Working Memory Underpins Cognitive Development, Learning, and Education. In Educational Psychology Review. https://doi.org/10.1007/s10648013-9246-y

Culp, W. C. (2020). Coronavirus Disease 2019. A \& A Practice, 14(6) e01218.

Do, Q. H., \& Chen, J. F. (2013). A neuro-fuzzy approach in the classification of students' academic performance. Computational Intelligence and Neuroscience. 2013, 1-7.

Donlan, J. (2014). De-extinction in a crisis discipline. Frontiers of Biogeography, 6(1), 25-28.

Fitriyadi, H. (2013). Integrasi Teknologi Informasi Komunikasi Dalam Pendidikan: Potensi Manfaat, Masyarakat Berbasis Pengetahuan, Pendidikan Nilai, Strategi Implementasi Dan Pengembangan Profesional. Pendidikan Teknologi Kejuruan, 
21(3) 269-284.

Gozali, A. (2020). Bimbingan Dan Konseling Berbasis Teknologi Informasi Pada Masa PSBB (Pembatasan Sosial Berskala Besar). Jurnal Bimbingan Konseling Pendidikan Islam Coution: Journal of Counseling and Education Layanan, 1(2) 36-49.

Hege, B. A. R. (2011). The Online Theology Classroom: Strategies for Engaging a Community of Distance Learners in a Hybrid Model of Online Education. Teaching Theology and Religion, 14(1) 13-20.

Honkapuro, S., Tuunanen, J., Valtonen, P., Partanen, J., Järventausta, P., Heljo, J., \& Harsia, P. (2015). Practical implementation of demand response in Finland. 23rd International Conference on Electricity Distribution (CIRED 2015).

Horspool, A., \& Lange, C. (2012). Applying the scholarship of teaching and learning: Student perceptions, behaviours and success online and face-to-face. Assessment and Evaluation in Higher Education, 37(1) 73-88.

Ippolito, M., Di Tria, G. B., Aldrigo, C., Ricci, M., Zoni, U., Giordano, A., \& Cozzolino, M. (2020). Standard procedures in dialysis during the Covid-19 epidemic. Giornale Italiano Di Nefrologia: Organo Ufficiale Della Societa Italiana Di Nefrologia, 37(3), 115-120.

Jenkins, J. (2014). Sickness absence in the labour market February 2014. Office for National Statistics, 10(2), 1-21.

Kahfi, A. (2020). Tantangan Dan Harapan Pembelajaran Jarak Jauh Di Masa Pandemi Covid 19. Dirasah, 3(2) 137-154.

Kizilcec, R. F., Davis, G. M., \& Cohen, G. L. (2017). Towards equal opportunities in MOOCs: Affirmation reduces gender \& social-class achievement gaps in China. L@S 2017 - Proceedings of the 4th (2017) ACM Conference on Learning at Scale. https://doi.org/10.1145/3051457.3051460

Kuntarto, E. (2017). Keefektifan Model Pembelajaran Daring Dalam Perkuliahan Bahasa Indonesia di Perguruan tinggi. Journal Indonesian Language Education and Literature, 3(1) 53-65.

Kweka, K. H., \& Ndibalema, P. (2018). Constraints Hindering Adoption of ICT in Government Secondary Schools in Tanzania: The Case of Hanang District. International Journal of Educational Technology and Learning, 4(2) 46-57.

Lameras, P., Levy, P., Paraskakis, I., \& Webber, S. (2012). Blended university teaching using virtual learning environments: Conceptions and approaches. Instructional Science, 40(1) 141-157.

Littlejohn, A., Hood, N., Milligan, C., \& Mustain, P. (2016). Learning in MOOCs: Motivations and self-regulated learning in MOOCs. Internet and Higher Education, 29(1), 40-48.

Macdicken, K., Reams, G., \& Freitas, J. De. (2015). Forest Ecology and Management Introduction to the Changes in Global Forest Resources from 1990 to. Forest Ecology and Management, 35(2), 3-8.

Miles, M. B., Huberman, A. M., \& Saldana, J. (2014). Qualitative Data Analysis + the Coding Manual for Qualitative Researchers, 20(1), 100-104.

Oproiu, G. C. (2015). A Study about Using E-learning Platform (Moodle) in University Teaching Process. Procedia - Social and Behavioral Sciences. https://doi.org/10.1016/j.sbspro.2015.02.140

Pakpahan, R., \& Fitriani, Y. (2020). Analisa Pemanfaatan Teknologi Informasi Dalam Pembelajaran Jarak Jauh Di Tengah Pandemi Virus Corona Covid-19. JISAMAR (Journal of Information System, Applied, Management, Accounting and Researh), 4(2) 30-36.

Pothkow, K., \& Hege, H. C. (2011). Positional uncertainty of isocontours: Condition 
analysis and probabilistic measures. IEEE Transactions on Visualization and Computer Graphics. 17(10), 1393-1406.

Puji Lestari, Y. (2020). Dampak Positif Pembelajaran Online Dalam Sistem Pendidikan Indonesia Pasca Pandemi Covid-19.

Ratnaya, I. G. (2011). Dampak Negatif Perkembangan Teknologi Informatika Dan Komunikasi Dan Cara Antisifasinya. Jurnal Pendidikan Teknologi Dan Kejuruan, $8(1), 17-28$.

Rosdiana, R. (2018). Pengembangan Media Pembelajaran Berbasis Komputer. AlKhwarizmi: Jurnal Pendidikan Matematika Dan Ilmu Pengetahuan Alam, 1(2), 87100.

Sangrà, A., González-Sanmamed, M., \& Anderson, T. (2015). Meta-analysis of the research about MOOC during 2013-2014. Educacion XX1, 18(2) 1-28.

Sari, I. N. (2019). Pengaruh Penggunaan Googleclassroom Terhadap Efektivitas Pembelajaran Mahasiswa Universitas Islam Indonesia. Yogyakarta. Universitas Islam Indonesia.

Sarip, S., Syarifudin, A., \& Muaz, A. (2020). Dampak Covid-19 Terhadap Perekonomian Masyarakat Dan Pembangunan Desa. Al-Mustashfa: Jurnal Penelitian Hukum Ekonomi Syariah, 5(1) 10.

Shishkovskaya, J., Sokolova, E., \& Chernaya, A. (2015). "Paperless" Foreign Languages Teaching. Procedia - Social and Behavioral Sciences, 206, 232-235.

Siregar, P. P., \& Zahra, A. H. (2020). Bencana Nasional Penyebaran COVID-19 sebagai Alasan Force Majeure, Apakah Bisa? Direktorat Jenderal Kekayaan Negara Kementerian Keuangan.

Sohrabi, C., Alsafi, Z., O’Neill, N., Khan, M., Kerwan, A., Al-Jabir, A., Iosifidis, C., \& Agha, R. (2020). Corrigendum to "World Health Organization declares Global Emergency: A review of the 2019 Novel Coronavirus (COVID-19)" [Int. J. Surg. 76 (2020) 71-76] (International Journal of Surgery (2020) 76 (71-76).

Suto, I. (2013). in Research Matters: A Cambridge Assessment Publication. In Camridge Assesment, 11(2), 1-28.

Syamsuar, \& Reflianto. (2019). Pendidikan Dan Tantangan Pembelajaran Berbasis Teknologi Informasi Di Era Revolusi Industri 4.0. In e-Tech: Jurnal Ilmiah Teknologi Pendidikan, 6(2) 1-13.

Utami, R. (2019). Analisis Respon Mahasiswa terhadap Penggunaan Google Classroom pada Mata Kuliah Psikologi Pembelajaran Matematika. Prisma, Prosiding Seminar Nasional Matematika. ISSN 2613-9189 (2019) 2 498-502.

Widiyono, A. (2020). Efektifitas Perkuliahan Daring (Online) pada Mahasiswa PGSD di Saat Pandemi Covid 19. Jurnal Pendidikan, 8(2) 169-177.

Windhiyana, E. (2020). Dampak Covid-19 Terhadap Kegiatan Pembelajaran Online Di Perguruan Tinggi Kristen Di Indonesia. Perspektif Ilmu Pendidikan, 34(1) 1-8.

Wu, J., Guo, S., Huang, H., Liu, W., \& Xiang, Y. (2018). Information and communications technologies for sustainable development goals: State-of-the-art, needs and perspectives. IEEE Communications Surveys and Tutorials, 20(3) 23892406. 